\title{
The Education Sector and the Crises of the Nigerian State
}

\author{
Ejitu N. OTA \\ Department of History and International Relations, \\ Abia State University, Uturu, Nigeria \\ E-mail: otaejitu@gmail.com \\ Chinyere S. Ecoma (Corresponding author) \\ Department of History and International Relations, \\ Veritas University, Abuja, Nigeria \\ E-mail: ecomachinyere@yahoo.com
}

Received: February 19, 2017 Accepted: April 7, 2017 Published: April 18, 2017

doi:10.5296/jad.v3i2.10774

URL: https:// doi.org/10.5296/10.5296/jad.v3i2.10774

\begin{abstract}
Opinions are varied on whether Nigeria is a failing or failed state. The inability of the ruling class to sustain the tempo achieved in the development of the country in the opening years of its independence has often agitated the minds of discerning and concerned citizens. Infrastructural decay, corruption, political ineptitude, declining economic conditions, social inequality, religious bigotry, and a general sense of insecurity have pervaded the country's domestic landscape. In particular, the declining fortunes of the education sector and the apparent official neglect of that sector have placed Nigeria's present and future on a dangerous pedestal. Education is synonymous with self-improvement and national development. Yet, its progress has stagnated and indeed deteriorated over the years. Heaping the blame on one cause is an exercise in futility. Rather, there should be concerted efforts at both the official and unofficial levels to checkmate the obvious decline in both the quality of education and its perception by the government as secondary to other national issues.
\end{abstract}

Keywords: Citizens, Corruption, Democracy, Development, Education, Polity, Poverty 


\section{Introduction}

To argue that there is a crisis in Nigeria's education sector is an unnecessary waste of both time and energy. In other words, the education sector in Nigeria is in very dire straits, and to argue otherwise is nothing short of self-deception. Yet, not much attention appears to have been paid to this sector by successive Nigerian governments, especially since 1970. In fact, the many years of military dictatorship rubbed the shine off Nigerian education. But civilian administrations have not fared any better. As a matter of fact, under the present democratic dispensation, Nigeria is yet to allocate the minimum United Nations Educational and Scientific and Cultural Organisation's (UNESCO) prescribed minimum of $26 \%$ of the annual national budget to the education sector. Out of the prescribed $26 \%$, Nigeria is said to be far behind. According to Adedipe (2013: 28), "Nigeria has been hovering around an average of 9 per cent when our neighbour, Ghana, which started its university system same year as Nigeria's in 1948, is reported to have exceeded the guiding minimum." In the same vein, the Director-General of UNESCO, Irina Bokova, has lamented on the parlous state of the education sector in Nigeria. In her words:

... about 10 million children are out of school [in Nigeria] and this represents a lot, against the background that in the world, there are 57 million children out of school; so it's (Nigeria's figure) almost 20 per cent of the number and that is huge (2013: 7).

Yet, there is no denying the fact that education is a basic human right and the surest route to individual self-actualisation and national transformation and development. That is why the Constitution of the Federal Republic of Nigeria 1999 (as amended on $10^{\text {th }}$ January 2011) has provided in Section 18, sub-sections (1), (2), and (3) that:

(1) Government shall direct its policy towards ensuring that there are equal and adequate education opportunities at all levels.

(2) Government shall promote science and technology.

(3) Government shall strive to eradicate illiteracy; and to this end government shall as and when practicable provide:

(a) free, compulsory and universal education;

(b) free university education; and

(c) free adult literacy programme.

In spite of this constitutional provision, the education sector in Nigeria is still in peril. In fact, in the first quarter of 2013, it is on record that for about three months at least, teachers in primary and secondary schools in eleven out of the thirty-six states in Nigeria were on strike over the refusal of the Federal Government to implement an agreement they reached over three years ago on remuneration and funding of public schools (ThisDay, 2013: 15). Similarly, in 2013, state-owned polytechnics went on strike for several months, while the Academic Staff Union of Universities (ASUU), the umbrella body of Nigerian university lecturers, 
embarked on a strike action between July and December 2013 to press home its demand for the implementation of agreements it entered into with the Federal Government since 2009. Scenarios like these make the topic of this paper very apt. For one thing, education in Nigeria should be given the priority it deserves if the Vision 20:20:20 and the Transformation Agenda of the Jonathan-led administration are to be actualised. In addition, ignoring the education sector will negate the objectives of the Millennium Development Goals (MDGs) and leave Nigeria behind in the global development agenda for the $21^{\text {st }}$ century. There is, therefore, a compelling need to take education as a very serious task that must be pursued with vigour and commitment.

Before delving into the topic, one must obey the age-long academic tradition of assigning definitions to some of the concepts used in this paper, especially education, polity and development, among others. Education has been defined as:

... the systematic socialisation of the younger members of the society into learning about the religion, morals, beliefs, feelings of nationality and collective opinions of all kinds. It embraces not only the planned and deliberate process of schools, colleges, but also the indirect and incidental experiences of life (Anuna, 2008a: 10-11).

In the context in which it is used here, therefore, education is instructing someone on what to do and develop him or herself. Accordingly, in as much as education has to do with an organised and systematic process of instruction (Okunamiri, 2005: 1) in a school environment, its major objective is to broaden one's knowledge base and the mental capacity, not only to improve and develop a person but more importantly to enhance the creative potentials of those who are exposed to education. In other words, an individual's skills and abilities are most likely to be realised and actualised through education, whether in the formal school system or the non-formal system of vocational and apprenticeship trainings. On its part, polity means government or state, and has to do with one form of political organisation or the other. Thus, in the context in which it is used here, the Nigerian polity simply refers to the Federal Republic of Nigeria.

Development is another important concept that needs clarification. As a popular concept, it has been subjected to a variety of interpretations. For our purposes here, development has to do with incremental qualitative changes in the lives of the citizens of a given state. Such changes must not only be people-oriented but also people-propelled. It also means the overall economic, social, cultural and political well-being of the polity. In other words, development is multifaceted and should not be equated with statistical records on the health of a state or country.

\section{A Brief History of Western Education in Nigeria}

Western education in Nigeria started with the activities of Christian missionaries after the abolition of slave trade in 1807. The Methodist Church, the Catholic Church, the Church Missionary Society (C.M.S.), as well as the Presbyterian Church (then known as the Church of Scotland Mission or C.S.M.), and the Anglican Church, were in the forefront of building 
mission-run schools in Nigeria. But their educational activities were concentrated mostly in the southern parts of the country, and attention was paid only to primary school education at the expense of secondary school education. Thus, only a few secondary schools were established by the missionaries, and these were run on limited funds which were subscribed by the local congregations and wealthy philanthropists (Osoba and Fajana, 1984: 570-571).

Among the earliest mission-run secondary schools were the CMS Grammar School (1859), the Roman Catholic Teachers College (later St. Gregory's College, Lagos and Methodist Boys' High School, Lagos) 1878. Products of these schools were mostly employed as clerks who were marginally literate, just like their counterparts from the primary schools who were employed mostly as interpreters in their localities. Yet, missions continued to dominate and monopolise education in colonial Southern Nigeria. A major reason for this was the unwillingness of the British colonial government to deploy its tax payers' monies to ventures it considered unprofitable. In the past, the colonial government placed low priority on education vis-à-vis the exploitation of the human and natural resources of Nigeria. When the colonial government began to show interest in educational development, its objective was to establish schools mainly for the production of such minor functionaries as clerks and junior technicians in public works, and sanitary inspectors, among others. Invariably, despite the introduction of various official measures intended to ensure proper supervision and control of education, and increased official funding of schools, the attention paid to the education sector was grossly inadequate. In effect, neither the Lagos Education Ordinance of 1882, nor the Southern Nigeria Education Code of 1903, nor the Education Ordinances of 1919 and 1926 respectively, could serve to effectively meet the needs of a modernising state like Nigeria.

The northern parts embraced Western education much later. Some reasons accounted for the North's relative late reception of Western-style education. One fact is that the North was geographically disadvantaged, lying close to the Sahara desert at a time when European missionaries were not willing to go beyond the coast. In addition, Northern Nigeria was predominantly Moslem, and its peoples had long embraced Islamic education. Lastly, there was the problem of British colonial rule. The colonial officials, in conjunction with the Emirs and the Northern Nigeria oligarchy, did not encourage Christian missionary and educational activities in the area. Because of an agreement between the Emirs and Frederick Lugard on the conditions under which the former would accept British overlordship, Lugard and his lieutenants bluntly refused to allow Christian missions to access the North. Thus, a combination of factors worked together to insulate and isolate Northern Nigeria from the pervasive Christian educational influences. What the North lost was what the South gained. By 1882, the colonial government had taken bold steps to encourage education in Nigeria instead of leaving Christian missions to remain the dominant force in that vital sector. In 1908, an Education Ordinance came into existence which stipulated the subjects that were to be taught in primary and post-primary schools. These included English Language and Literature, History, Geography, Nature Study, Reading, Grammar, Writing, Arithmetic, Physical Education, among others (Ejifugha, 1999: 103).

In 1916, after the amalgamation of the Northern and Southern Protectorates (1914), Lugard had to abrogate the Education Ordinance because of his belief that education in the southern 
parts had only succeeded in breeding an army of discontented, stubborn and arrogant individuals who had exaggerated opinions of their importance and relevance in the colonial system. He therefore proposed an Education Code which sought to use schools as platforms for the formation of character and good discipline. To him, the acquisition of knowledge and skills without character and habits of discipline was a waste (Ogunsola, 1974: 18). On the contrary, he firmly believed that education should seek to produce clerks and teachers, not radicals that will oppose British colonial rule. But the Education Code was never implemented in the North and this contributed to the backwardness of that region in the area of Western education. Although Lugard later appointed Han Vischer to oversee education in Northern Nigeria, the latter, after extensive tours of Egypt, Sudan and Ghana (formerly known as Gold Coast), proposed which was contrary to Lugard's expectations, that Christian missions should be free to go to the Moslem-dominated areas and expand their missionary and educational activities there. He also recommended that government schools should be limited to Moslem enclaves (Anuna, 2008b: 277-278).

Over the years, however, the colonial government instituted a number of commissions and panels that enabled it to appraise its policy on education. The most important of these was the Phelps Stokes Commission, which submitted a memorandum in 1925 that showed inadequate cooperation among the Christian missions, European trading companies, and the colonial government. In a similar vein, the Education Ordinance of 1948 sought to harmonise and rationalise the education system in the North and South, taking into cognisance the regionalisation of Nigeria which the 1946 Richards Constitution introduced. But the North continued to lag woefully behind, essentially because of the earlier decision of Lugard not to permit Christian missionaries to penetrate the predominantly Moslem areas. But the so-called "pagan" areas in the North (present-day Plateau, Benue and Kogi States) fared better than the far North in educational advancement. In the 1950s, both the Western and Eastern regional governments adopted universal primary education in 1955 and 1957 respectively. The North had to wait till 1961 to inaugurate the Oldman Commission to articulate policies on primary and secondary education management. Meanwhile, the Western and Eastern regions had set up commissions to ensure quality in education reforms before 1960 (Ibid: 288).

There had been a growing realisation by some enlightened Nigerians of the imperatives of Western education as an instrument for social and economic self-improvement. These groups of Nigerians were at the forefront of the demand not only for qualitative mass education but also for education beyond the primary school and secondary school levels. However, the colonial government was not favourably disposed to such a demand. For the government, the idea of acceding to the demand for higher education for Nigerians was suicidal because it would mean permitting and indeed encouraging them to take over the running of their country from British colonial officers.

In 1934, the Yaba Higher College was formally opened after it had existed and operated in temporary quarters for two years. Essentially, the College was set up to train and provide assistants to European government officials and commercial firms. The demand by Nigerians for its upgrading to a university did not appeal to the British colonial government. Establishing a university in Nigeria was simply unimaginable because of the fear that 
colonial officials would be displeased from their advantage positions by well-educated Nigerians. It was the report of the Elliot Commission of 1943 that heralded the beginning of higher education in Nigeria. That report had advised the colonial government to establish and affiliate a University College at Ibadan to the University of London. This was done in 1948. A year later, the E. J. Harlow committee recommended the establishment of a College of Arts, Science and Technology in Enugu, Ibadan, and Zaria. These were opened in 1952 and were later absorbed by the University of Nigeria, Nsukka, the University of Ibadan, and the Ahmadu Bello University, respectively. Thus, beginning with the Yaba Higher College which was meant to produce middle-level manpower, higher education in Nigeria received a boost with the colonial government's decision to jettison its opposition to higher education in the country. This was made manifest in the establishment of three Colleges of Arts, Science and Technology in the three regions and their later metamorphosis into universities.

\section{Education and National Development in Nigeria}

The importance of education in national development cannot be over-emphasised. At the individual level, education helps in expanding one's knowledge and worldview. Since every country is made up of individual citizens, it follows logically that no nation can rise above the level of education which its citizens have acquired. In other words, the more educated a country's citizens are (that is qualitatively), the more creative they become and the more developed and prosperous the country.

Since political independence in 1960, Nigeria has not been able to attain any appreciable level of development when compared with countries like Malaysia, Singapore, and South Korea- countries with which she shared a lot in common a few years ago but which are now far ahead of her in all indices of development. Part of the explanation for this dismal performance is to be found in the lackadaisical attitude of Nigerian leaders to education. It is true that the primary goal of education is to teach students how to think and be creative and how to be functional in their respective societies and the nation at large (Onakemu, 2012: 53). Unfortunately, Nigerian leaders have failed to realise that education is one critical area that has to be taken seriously if any well thought-out blueprint of socio-economic transformation and political stability is to be actualised. As has rightly been observed by Ogar (2013: 42), "Countries which have made the greatest progress in reducing poverty in recent decades are those which have combined effective and qualitative investment in education with sound economic policies." This is historically true. The world's most technologically and economically advanced countries have a history of investing heavily in education. Japan, for instance, was not only defeated in World War II (1936 - 1945) but was also heavily indemnified, just like Germany and Italy (the other two countries of the Axis powers during the war). Yet by 1947, Emperor Hirohito's massive investment in education in Japan began to bear so much fruits that today, Japan is considered one of the most developed countries in the world. Before 1914, Vladimir Lenin had transformed Russia from a poverty-stricken backward country to a modern state through investment in education.

Back home in Nigeria, it was education that enabled our nationalists to question the legitimacy of British colonial rule in the country. Nnamdi Azikiwe who was the most 


\section{MInstitute ${ }^{\text {Macrothink }}$}

vociferous critic of British colonial rule had acquired university education in the United States of America and had been exposed to the democratic culture of that country. To him, therefore, the subjugation and exploitation of Nigeria's human and material resources by the British colonial regime was unjustifiable. That was why he took it upon himself to establish the first indigenous university in the country (the University of Nigeria, Nsukka) in 1960. Other universities quickly sprang up, in addition to the University College, Ibadan, which the colonialists had established in 1948 as a campus of the University of London. The new universities were: the University of Lagos, the University of Ife, and the Ahmadu Bello University, Zaria, which were all established in 1962. Today, there are at least seventy-four public universities in Nigeria (Onyekanmi, 2012: 2). There are also several Polytechnics, Colleges of Education, Colleges of Health Technology, Colleges of Agriculture, as well as many private universities, polytechnics, and colleges.

At first glance, one would have the impression that there are too many tertiary institutions in Nigeria. But that is really not true. With a population estimated at 150 million and having less than 120 universities, Nigeria does not compare either with Argentina with a population of 38 million and about 1,758 universities, the United States with a population of about 300 million and 5,758 universities, or India with a population of one billion and 8,407 universities (Ogbuagu, 2006: 70). Even at the primary and secondary school levels, Nigeria is not anywhere near what it should be. In fact, as Fafunwa (1974: 168) has rightly pointed out: "Educational development is imperative and urgent. It must be treated as a national emergency second only to war. It must move with the momentum of a revolution". It is true that educational advancement was far more competitive in the period before and soon after independence than it is today. At that time, the regional governments all had universities in their regions, while the Western Region had introduced the Universal Primary Education (UPE) Programme as early as 1955 and witnessed an unprecedented enrolment of pupils in primary schools. The Western Region under the Action Group (AG) had led the way while the Eastern Region under the National Council for Nigerian Citizens (NCNC) was able to articulate a similar programme for the region and began its implementation in 1957. As usual, the ultra-conservative Northern Nigeria oligarchy, which dominated the Northern Peoples' Congress (NPC) was not keen on encouraging Western education in the region. This resulted in a wide chasm in educational attainment between the two regions in the South and the Northern region. This gulf is yet to be bridged and has continued to be politicised.

Educational development at the secondary and tertiary levels was given a boost following the acceptance in September 1960 of the report of the Eric Ashby Commission which had been set up to investigate Nigeria's needs in the area of secondary and tertiary education. The report was instrumental to educational advancement in the post-independence era, with the regional and federal governments investing more in education. Thus, against the 30,000 annual intakes of secondary school students envisaged in the Ashby report, the total enrolment in 1960 was 135,434 which rose to 211,879 in 1963 (Taiwo, 1980: 141). At this time, education was attractive and became the major yardstick for assessing the progress of the three regions. In particular, the establishment of universities (five of them between 1960 and 1963) was a major milestone. According to Onwuka (2008: 89): 
They have, since their establishment epitomised academic excellence and gone a long way in realising the objectives which informed their establishment by being the major high level manpower laboratories of the nation and becoming consciously or otherwise a yardstick for rating or scaling later universities not only in Nigeria but also in the West African sub-region and beyond.

It has also been observed that during the 1960s and up to the early 1980 s, the quality of university education in Nigeria was so high that it was highly rated and attracted both lecturers and students from other countries. Quoting Tom Burgis of the Financial Times, Toyin Akinosho wrote that, "Nigeria had functional educational system in the sixties .... Some of your best brains graduated in that system" (2012: 23). The sub-optimal performance of the educational system in Nigeria is indeed worrisome and is partly responsible for the country's inability and failure to develop and compete with others in the international arena.

The glorious days of functional education, especially at the tertiary level, has given way to the injection into the society of functional illiterates who cannot defend their certificates. This army of unemployed and unemployable but certified graduates is the product of a decadent society bereft of committed leadership. They are the victims of a nation whose leaders have refused to invest in qualitative educational development. To quote a source, “... a nation that expects to develop in spite of its illiterate masses expects what never was and never shall be" (Daily Independent, 2013: 31). Nigeria is at crossroads today. She cannot join the league of developed countries unless she restructures her education system. As evidenced by recent ranking of universities in the world, no Nigerian university was rated among the best 85 universities out of the 7,000 world recognised universities. None made the list of the first 100 . It was only the University of Cape Town, South Africa, that was ranked 156 by the Quacquarell Symonds ranking group in 2011 in all of Africa. Meanwhile, universities in the United States and Britain as well as Canada, Switzerland and Hong Kong were highly rated (Orgu, 2012: 35). The situation is such that rich Nigerians are now competing with each other over who would have the most of their children attend foreign universities not only in Europe and North America but also in Ghana, China, and South Africa. In these countries, education is functional and qualitative because their governments are committed to educational development. For example, while Nigeria devotes less than ten per cent of her annual budget to education, Ghana and Kenya have exceeded the UNESCO benchmark of twenty-six percent.

Consequent upon the rot in Nigeria's education system, many young Nigerians from wealthy backgrounds are shunning the universities here, preferring to study abroad. In 2009, the Network of Migration Research on Africa (NORMA) ranked Nigeria third on the list of countries with the highest number of students studying abroad. Similarly, in 2010, Business Day online reported that Nigerian students in the United Kingdom spent $\$ 246$ billion annually on education, while over 71,000 Nigerians studying in Ghana pay about $\$ 155$ billion annually. Meanwhile, the Federal Government's annual budget for all federal universities in Nigeria was a meagre $\$ 121$ billion (Ibid). 


\section{The Rot in the Education Sector: Causes and Implications}

Indeed, there is decay, a rot in the education sector of Nigeria. Beginning from the primary and secondary levels up to the tertiary level, education has remained the least priority of successive governments. Funding has been poor and this has forced teachers at all levels to embark on strikes intended to draw the government's attention to the need to save education. The neglect is suffocating and has led to the so-called brain-drain whereby qualified professionals and university lecturers have had to move to other countries with favourable academic and professional environments to ply their trades. In his welcome address at the Conference on Reforming Higher Education in Nigeria organised by the Academic Staff Union of Universities (ASUU) and the Council for the Development of Social Science Research in Africa (CODESRIA) on $21^{\text {st }}$ and $22^{\text {nd }}$ March, 2005 at Abuja, the then president of ASUU, Dr. Abdullahi Sule-Kano, had noted that:

The aspirations of the Nigerian people for education demand that we see education not as merely in terms of manpower development. Education is a public good directed at uplifting the social, scientific, technological and cultural development of the Nation, as well as developing the talents of individual citizens... Education is not a commodity just for sale. It is a social good. It is the social responsibility of any government to its people. It is the engine of growth, development and transformation of any society. Higher education restores to mankind its humanity (2005: 4).

This remark, to say the least, is a lamentation of a concerned Nigerian on the fate of education generally and tertiary education in particular. Demand for access to education is increasing, while government's funding of the sector is declining. The lingering consequences include the high dropout rate of students, especially boys. A pertinent question to pose here is, "How did we ever get into this mess?"

\subsection{Causes of the Rot in the Education Sector}

A number of factors are responsible for the parlous state of Nigeria's education system. Among those that have been isolated are the following:

i. Politics,

ii. Corruption,

iii. Infrastructural decay,

iv. Inadequate capacity building and low morale of teachers,

v. Poverty,

vi. Policy somersaults and inconsistencies.

\subsubsection{Politics}

We alluded earlier to the fact that Western education was encouraged in the southern parts of 
colonial Nigeria, unlike in the North where the colonial officials adopted a deliberate policy of preventing Christian missions from establishing schools. The result has been the widening gap between educational developments in the two regions. Since 1960, the North has been working hard to catch up with the south in the area of education.

The intrusion of the military into national politics, especially since 1970, saw the introduction of a number of official policies meant to bridge the gap. We need to be reminded that for the nearly thirty years that the military was in power, its top hierarchy was dominated by elements from the former Northern region. Educational policies became politicised, and sought basically to reduce, at all cost, the inequality between the South and the North. From 1970 when the government took over schools (primary, secondary, and tertiary), policies like the federal character and quota system were introduced as criteria for admitting students into federal government-owned secondary schools and institutions of higher learning. Some states, especially in the North, were designated as "educationally disadvantaged". To make them "catch up" with those in the South, candidates from the so-called disadvantaged states were offered admission into government-owned schools with lower scores vis-à-vis those from the South. To say that this obnoxious policy has greatly affected, in a negative way, educational development in Nigeria, is to state the obvious. Quality and merit have been compromised on the altar of politics.

In the area of funding primary education in Nigeria, the Act establishing the Universal Basic Education (UBE) provided that education fund should be disbursed based on the following:

1. $50 \%$ on the basis of equality of state;

2. $30 \%$ on the basis of school enrolment; and

3. $20 \%$ to all the so-called educationally disadvantaged states (Anuna, 2008c: 316).

By obvious implication, the states considered educationally-advantaged (which are mostly in the South and which have the highest enrolment of primary school pupils), are officially starved of funds to pay teachers and provide essential infrastructure. Conversely, the North which has the bulk of the educationally-disadvantaged states has sufficient funding even when it has less enrolment. In other words, the disadvantaged Northern states with less enrolment have $100 \%$ fund, while their advantaged counterparts in the South have only $80 \%$ of the funds (Ibid). This disparity in the official funding of primary education in Nigeria is unhealthy.

Equally, the admission policy into federal government-owned schools (secondary and tertiary), has continued to be a very sensitive and controversial issue. It is no secret that candidates from the Northern states are offered admission into the so-called "Unity schools" (Federal Government Colleges) with scores far lower than what their counterparts from the South have. Similarly, the location of federal government-owned tertiary institutions has been influenced more by a warped sense of a need to ensure geo-political balance as against felt need or any other realistic considerations. In the end, the application of the federal character principle and the quota system has invariably resulted in the production of low-quality graduates from the secondary schools and tertiary institutions. To quote one source, the 
adoption of discriminatory policies on primary school funding and admission into federal government-owned schools which were foisted on the country by military dictators, is a reflection of:

... the decay in the country's educational system. It is a signal that Nigeria's educational sector ... has got to a level where it can no longer produce brilliant students who could be given admission into tertiary institutions, a situation which is capable of affecting Nigeria's march towards social, economic and technological advancement (Daily Independent, 2013: 31).

It needs to be stressed here that the politicisation of education is against common sense as there has never been any lasting benefits anywhere in the world from the implementation of policies that tend to hold one section down to the advantage of another.

\subsubsection{Corruption}

There is no universally accepted definition of corruption, though the United Nations has adopted a descriptive approach which has clearly highlighted such acts as bribery, embezzlement, illicit enrichment, abuse of power, laundering of proceeds of corruption, obstruction of justice, et cetera, as corrupt acts (Ogunlana, 2007: 5). For our purposes here, corruption is defined as the use of public office to amass personal wealth illegally (Ota, 2012: 205). Put differently, when we talk of corruption, we mean any anti-social behaviour that confers on an individual or a group some benefits that are not only improper and immoral, but also illegal (Osoba, 1996: 371).

Going down memory lane on the history of corruption in Nigeria, Osoba has lamented that:

In Nigeria it [corruption] became the principal means of private accumulation during the decolonisation period, in the absence of other means, and came to shape political activity and competition after independence. All subsequent regimes, military and civilian, have been pervaded by corruption. Aided and enhanced by oil revenue, this has created a deepening crisis of kleptocracy, shown in its most extreme form since 1984. It results in a combination of scandalous wealth among the ruling class with growing poverty, misery and degradation among the mass of Nigerians. Political life has become dominated by winner-take all factional struggles, political cynicism and violence, while the economy and social institutions have been driven into decay. Corruption has thus become a way of life in Nigeria, one which existing governments neither wish (sic) to, nor can, control (Ibid).

Corruption in Nigeria was consolidated by military rule, especially since 1976 during the Murtala Mohammed - Olusegun Obasanjo military regime. According to Osoba, many of the generation of military officers who served under Murtala and Obasanjo made inexplicable gargantuan fortunes (Ibid: 379). Corruption in Nigeria reached a crescendo when Ibrahim 
Babangida became military Head of State in 1985 . To quote Osoba once again:

The main distinguishing feature of corruption in the Babangida regime was the pervasive culture of impunity: any of his acolytes, however high or low in status, could loot the treasury to their heart's content with impunity, provided they remained absolutely loyal and committed to the leader (Ibid: 382).

Democratically elected governments have not fared any better. Part of the justification the Muhammadu Buhari-Idiagbon regime gave for overthrowing the civilian government of Shehu Shagari in late 1983 was the failure of that government to stem the tide of corruption in Nigeria. The Shagari-led government is said to have embarked on a squandermania of epic proportions which saw the emergence of emergency millionaires from members of the political class and their cronies. Yet, the government could not pay salaries and wages to civil servants and teachers for several months but continued instead to borrow extensively, boosting the country's debt stock from 6.8 billion U.S. dollars in 1979 to 15 billion dollars in December 1983 (Ibid: 380).

Between 1999 and now, corruption has continued to pose a threat to national development. As a matter of fact, since 2005, Transparency International, through its Corruption Perception Index (CPI) has continuously rated Nigeria as one of the most corrupt countries in the world. The most pervasive form of corruption during the period under review is grand corruption, which is said to occur at the highest level of government and involves enormous monetary value. It also impacts heavily on the budget and growth prospect (Ogunlana, 2007: 6). The Lemu Panel on the 2011 Election Violence and Civil Disturbances, as well as the former Governor of Nigeria's Central Bank, Sanusi Lamido Sanusi, and Nigeria's former Education Minister, Oby Ezekwesili, have accused the executive arm of government and the National Assembly of financial profligacy at various times. In submitting the report of the panel he headed, Sheikh Ahmed Lemu is quoted as having observed that:

What these legislators take from the public coffers under the guise of allowances, whether in terms of their oversight function or travelling or any other allowance, cannot be justified by the relevant provisions of the constitution in this regard (Soniyi, 2013: 6).

On her part, Oby Ezekwesili is quoted as having accused the National Assembly of guzzling One trillion Naira ( $\$ 1$ trillion) in eight years, a figure she described as a huge drain on the economy. She referred to a report by the influential Economist Magazine which said that Nigeria's federal legislators, with a basic salary of 189,500 dollars per annum, were the highest paid lawmakers in the world. Back in 2010, Sanusi Lamido Sanusi had presented to Nigerians, through televised proceedings in the Senate, a very expensive National Assembly that has allocated $\$ 136.25$ billion (or $25.41 \%$ ) out of a total federal overhead of $\$ 536.2$ billion per annum (Chinweizu, 2013: 15).

It is, thus, an irony that more than $25 \%$ of Nigeria's annual budget goes into servicing the political class, while less than $10 \%$ is committed to the education sector. This is indeed a very 
sad commentary on the leadership of a country that prides itself as the giant of Africa.

\title{
4.1.3 Infrastructural Decay
}

One prominent victim of corruption in Nigeria is the education sector. Money that should have been deployed to upgrading facilities and infrastructure in primary and secondary schools as well as tertiary institutions, are embezzled by those who had sworn on oath to lead Nigeria. The pathetic state of infrastructure in primary and secondary schools is aptly captured by the observation that:

\begin{abstract}
At the primary and post-primary levels, many students are taught under trees and some in the open due to lack of classrooms. Many do not even know how the inside of a laboratory looks like, as they have never seen one before. Libraries are not available in most primary and secondary schools, and where there is a room labelled as such, it is usually bare with no books and journals. It is now a common sight to see students receiving lectures standing or perching on windows due to shortage of desks and benches (Akintunde, 2009: 11).
\end{abstract}

On December 2, 2013, it was reported that a human-rights group- Socio-Economic and Accountability Project (SERAP) asked the Lagos State Government to furnish it with detailed information of five years' finances which the government had spent on public primary and secondary schools in the state. According to the report, a letter by SERAP to the Lagos State government read, inter alia:

SERAP is seriously concerned about decay in infrastructure in public primary and secondary schools across the state .... Many pupils in these ... schools continue to sit on the bare floor in some classes while lessons are going on. The classrooms are overcrowded with several broken chairs and desks. Pupils are also reportedly forced to work to repair broken chairs and desks, something which would amount to forced labour (Adesomoju, 2013: 6).

This is based on the government's failure to account for a 90 million U.S. dollar loan which it had received from the World Bank to improve education in the 639 public secondary schools in the state (Ibid).

The situation is not different from what obtains in the country's tertiary institutions. Nigerian universities, as we noted earlier, are poorly rated globally, and given the high level infrastructural decay in them, the situation is unlikely to change soon. In fact, part of the reasons why the Academic Staff Union of Universities (ASUU) has often resorted to strike action is to draw the government's attention to the neglect and rot of infrastructure in the universities and other tertiary institutions. In these institutions, there have been steady demands for enrolment. Yet, their numerical strength has not been matched by commensurate provisions by government in the areas of staffing and funding (Sall, 2006: 16). 
4.1.4 Inadequate Capacity-Building and Low Morale of Teachers

Teachers, whether at the nursery, primary, secondary, or tertiary level, are in a fiduciary relationship with both the students and their parents/guardians. In other words, the student is entrusted to the teacher by his/her parents or guardians. The confidence parents have in teachers is immense. They are naturally expected to mould the characters of the next generation of leaders. To do this, teachers are expected to work with full commitment and to serve as role models for their students.

However, teachers are not motivated by either the government or the parents of their students. Remuneration is poor and irregular, and refresher courses to update teachers on global benchmarks for teaching and research are not among the priorities of government. The long-term implication is that teachers are compelled to engage in back-up activities to augment their wages at the expense of their calling. Also, many Nigerian graduates are shunning the teaching profession. This, according to Akinola Ajibade, is because unlike their counterparts in Europe and the United States, Nigerian teachers are not well remunerated and are generally not well treated (2012: 38). There is a virtual collapse in the country's value system occasioned and sustained by very corrupt leaders. Thus, teachers who were once regarded as instruments for shaping and reflecting the acceptable behavioural patterns in the society are now losing relevance in contemporary Nigeria.

In the tertiary institutions, lecturers are not faring better. The Nigerian university lecturer remains the lowest paid in Africa, with a senior Professor earning less than Six Hundred Thousand Naira a month; whereas a State High Court Judge earns about Two Million Naira a month. It is on record that the annual salary of a University Professor in Nigeria is $\$ 3.8$ million per annum, while a Local Government Chairman earns $\$ 13.9$ million per annum, while a Permanent Secretary, an Executive Secretary and Chief Executives of parastatals earn about $\$ 22$ million per annum. Similarly, a Federal High Court Judge earns about \$26.8 million a year; a member of the House of Representatives earns $\$ 35.9$ million a year, while the annual salary of a Senator is $\$ 36.6$ million (Akintunde, 2009: 12).

Out of about 51 private universities and 78 federal and state universities, the ratio of students to lecturers has continued to widen (Taiwo-Oguntuase, 2013: 37) and only about $43 \%$ of lecturers have doctorate degrees (Ph.D) out of a total of about 37,504 lecturers in public universities. Also, 57\% of lecturers in public universities do not have doctorate degrees (Onyekanmi, 2012: 2). This unfortunate scenario could be attributed to a number of factors, including lack of motivation and the necessary facilities and funding to encourage lecturers to go for Ph.D programmes. Those who possess doctorate degrees are forced by circumstances to teach in several universities at the same time. Obviously, the challenge of augmenting their meagre wages, through teaching outside their campuses, impacts negatively on researches and postgraduate supervision of many senior academics.

\subsubsection{Poverty}

Poverty in Nigeria is an inevitable corollary to poor leadership and corruption. It means lack of access to income and by extension, inability to purchase essential goods and pay for 
necessary services. In 2010, a report by the United Nations Development Programme (UNDP) ranked Nigeria a lowly $42^{\text {nd }}$ out of 169 countries in terms of human development indicators, with life expectancy at 48.44 years, far below 17 other African countries (The Guardian, 2010: 19). In the area of food security which has to do with food availability, food accessibility, and food utilisation, about $65 \%$ of the population does not have access to the amount and variety of foods necessary for productive life. About $40 \%$ of children less than five years of age are malnourished and about 25\% are underweight (Nwosu, 2011: 1-2).

It is because of poverty that many children in primary and secondary schools drop out of school. They become child labourers and miscreants. In 2012, a UNESCO report revealed that in general, boys are more likely to start school than girls, but are also at greater risk of repeating classes and dropping out of school totally. According to the report which was published in the Global Education Digest:

... the most important issues shaping educational opportunities are household wealth and location. In general, poor children living in rural areas are more likely than urban children from rich households to repeat grades and leave school before completing primary education and attaining basic foundational skills (DemoCrazy, 2001: $3)$.

This grim picture is worrisome because if the leaders of tomorrow are not properly educated today, the nation may slide into an abyss of barbarism and misery if and when they assume leadership positions.

\subsubsection{Policy Somersaults and Inconsistencies}

Generally, a policy means a plan of action anchored on acceptable principles and agreed to by an individual or a group of individuals or even an organisation. Educational policies refer to official government plans intended to elicit positive impacts on the education system. In other words, they mean decisions taken by government to actualise the objectives or goals of the education system. Such a plan of action involves three things, namely:

1. The identification of the objectives or goals;

2. The formulation of the right policies; and

3. The implementation of the plan.

Nigeria has witnessed a lot of somersaults and inconsistencies in her educational policies, especially at the primary and secondary school levels. For instance, the country has experimented, at various times, with the Universal Primary Education (UPE), as well as the 6-5-4 system and the 6-3-3-4 system. It is now trying out the Universal Basic Education system which provides for a nine-year universal, free and compulsory education for all Nigerian children. The system is intended to cover six years of primary education and three years of Junior Secondary school education. The current UBE system is the 9-3-4 disposition.

Because of pervasive poverty in the country, many children of school age are not benefiting 
optimally from the scheme. Many drop out of school due to the exigencies of helping their parents in their vocations or as child labourers in the urban areas. Thus, in as much as the intended beneficiaries of the scheme are supposed to have a solid foundation for literacy, especially at the grassroots level, poverty has denied many of them the opportunity.

Furthermore, the inconsistencies in education policies and the continued use of outdated curricula mean that children may end up repeating the same subjects under different titles. For instance, what actually is the difference between Civic Education and Social Studies? When subjects are lumped together like this, the obvious implication is that the children would be overstretched. That is why the current UBE programme has been roundly condemned as having been hastily launched without adequate planning and the sourcing of accurate and reliable data concerning the educational needs of the different parts of Nigeria (Ibid). In particular, it has been observed that the policy failed to decentralise education at the primary and secondary school levels to the states and local governments which are in a better position to deal with the peculiarities of their own parts of Nigeria (Nnodim, 2013: 33). Earlier policies, especially the 1977 National Policy on Education, which was reviewed in 1981, 1998, and 2007, do not seem to have placed the needed emphasis on technical education. The relegation of technical education to the background is regrettable because Nigerians have come to develop an attitude to that section of education which is seen as inferior. Thus, more candidates apply for admission into the universities than polytechnics. Many of those who graduate from the universities hardly have any form of technical training for self-employment. They, therefore, remain largely unemployable in an economy that is not expanding.

\section{Towards a Revitalisation of the Education Sector}

Every modern surgery begins with a diagnosis. So it is with this research paper. The factors or conditions that have virtually ruined Nigeria's education system have been identified. A revitalisation of the system would invariably involve finding relevant solutions to the identified problem areas. Such a move would fast-track the advancement of the education sector. It will also make the teaching profession very attractive. When that happens, the quality of teachers as well as their products will help in driving the national economy towards meeting the challenges of the $21^{\text {st }}$ century. When teaching is re-branded and becomes attractive, its practitioners will be committed and their morale will be boosted. Their importance and relevance to the society will also be appreciated.

One way, therefore, of revitalising education in Nigeria is through the creation of an enabling environment that will take into cognisance adequate funding of schools, regular and adequate remuneration of teachers, as well as capacity building. The UNESCO benchmark of $26 \%$ of the annual budget of Third World countries to the education sector has to be adhered to. It is only when the facilities and infrastructure are on ground that the recommendation of UNESCO for one teacher to be attached to twenty-six students can work. Not doing so would amount to teachers not attending properly and personally to their pupils and students and improving their understanding of what they are being taught.

It is also important for policy makers to encourage teachers to go on refresher courses in 
order to improve their teaching skills. Teaching is a calling, and periodic reviews of the educational curricula will help to provide standard and functional education. This, coupled with other incentives, will impact very positively on the development of the country.

At the tertiary level, there is an urgent need to increase funding and improve the material well-being of both lecturers and students. This way, strikes by lecturers, overcrowding in classrooms and hostels by students, brain drain, and cultism will be minimised, if not totally eradicated. Furthermore, tertiary institutions should be granted autonomy in choosing their Vice-Chancellors, Rectors and Provosts, as well as the composition of Governing Councils. The governments' meddlesomeness in this area is a direct fall-out of their take-over of tertiary institutions since 1970 .

Most importantly, the country needs really democratic, visionary and transformational leadership. Such leadership will not only be able to give clearly defined objectives, but will also co-ordinate, control and direct, guide and mobilise the efforts of the citizens, and maintain the integrity and mobility of the country towards achieving real development that is people-oriented and people-propelled. The leadership must be innovative and must display a huge capacity to tackle corruption, which is at the root of many of the problems confronting not only the education sector but also all of Nigeria's development programmes and policies. Leadership, after all, is about planning, vision, communication and creative action (Idowu, 2003: 27). If there are leaders who are committed to ensuring the best for the citizens, corruption could be contained and the money being squandered by the ruling class will be appropriately channelled into areas of need, such as education, job creation, roads and rural infrastructure, agriculture, healthcare, et cetera.

\section{Conclusion}

Education is the bedrock of every development process. That is why the UNESCO set a benchmark of $26 \%$ of the annual budgets of countries like Nigeria, for the education sector. But Nigeria has not lived up to expectations. Education has not been given its due place as the pivot of the country's social development, mobilisation and ethical reorientation (Ibid). The current pathetic nature of the education sector is a function of leadership amnesia. The military regimes, which ruled Nigeria for many years, were made up of mostly functional illiterates. That is why education was neglected and abused through the introduction and implementation of policies that only tended to commodify education. Poor funding combined with the obscurantism of the military leaders in stultifying the growth and development of education and by extension the advancement of the Nigerian state.

Without appropriate motivation for teachers, functional curricula, and infrastructural facilities at all levels of education, Nigeria's drive for development has remained perilous. This has not been helped by the high poverty level in the country and the attendant school dropout rate, especially in primary and secondary schools. Even among university students, there is a noticeable decline in the reading culture due to a number of factors. These include laziness on the part of students who would rather watch television or play with computers, as well as the harsh economic realities which have made many to give more attention to economic survival and material well-being. That is why the Nigerian education system, which was once among 
the best in the world, is today facing a lot of challenges. There is no denying the fact that the lack of quality education at the primary and secondary levels has had very deleterious consequences on the quality of candidates applying for admission into tertiary institutions. The result is that the cut-off marks for admission into universities and other tertiary institutions have continued to be lowered in order to accommodate so many weak candidates. The obnoxious principles introduced by the military regimes and still sustained by civilian governments are detrimental to producing quality graduates. Policies like those of "catchment areas", "educationally-disadvantaged states", and the "quota system" as criteria for admission into Federal government-owned institutions should be abrogated.

Similarly, the current educational system, especially at the tertiary level, needs to be reviewed. The philosophy, structure and curricula should include some aspects of indigenous knowledge and traditions rather than aping what obtains in foreign countries. If the country must produce leaders who will transform those they lead, emphasis should be on the type of education that will not only make the products of the system learn and understand, and critically analyse and modify their environment, but also qualitative with due regard to moral and religious values (Ibid).

\section{References}

Adedipe, N. (2013). "Contemporary Issues of Pains and Gains in the Nigerian University System”, The Guardian Newspaper, Sunday, November 24, p. 28.

Adesomoju, A. (2013). "SERAP asks Lagos for Information on Education Finances, The Punch Newspaper, Monday, December 2, p. 6.

Ajibade, A. (2012). "Wanted! 1.3 Million Teachers", The Nation Newspaper, Monday, November 26, p.38.

Akinosho, T. (2012). "My Country is Rich in Oil, so why am I so poor", The Guardian Newspaper, Wednesday, November 14, p. 23.

Akintunde, K. (2009). “Citadels of Decay”, Newswatch Magazine, October 5, pp. 11-12.

Anuna, M. C. (2008a). "Education and Policy in Nigeria", in J. M. Kosemani and M. C. Anuna (eds.), Politics of Education: The Nigerian Perspective (2nd ed., pp. 10-11). Enugu: El Demak Publishers.

Anuna, M. C. (2008b). "Educational Underdevelopment in Northern Nigeria and the British Colonial Policy: A Socio-Political Analysis of Interrelated Factors", in J. M. Kosemani and M. C. Anuna (eds.), Politics of Education: The Nigerian Perspective (2nd ed., pp. 277-278). Enugu: El Demak Publishers.

Anuna, M. C. (2008c). "Politics and the Implementation of Educational Policies in Nigeria", in J. M. Kosemani and M. C. Anuna (eds.), Politics of Education: The Nigerian Perspective (2nd ed., p. 316). Enugu: El Demak Publishers.

Bokova, I. (2013). "Why UNESCO will Continue to be Relevant", The Guardian Newspaper, Monday, November 25, p. 7. 
Chinweizu, A. (2013). "National Assembly: What Role in the Confab Process?" The Guardian Newspaper, Monday, November 25, p. 15.

Constitution of the Federal Republic of Nigeria 1999 (as amended). Federal Republic of Nigeria.

Daily Independent Newspaper (2013). "Editorial”, Monday, July 1, p. 31.

DemoCrazy: A Newsletter for the African Centre for Democratic Governance. (2001). Vol. 3, No. 3, May 29, p. 3.

Ejifugha, A. U. (1999). Development of Health Education in Nigeria. Owerri: Canun Publishers Nig. Ltd.

Fafunwa, B. A. (1974). History of Education in Nigeria. London: George Allen and Unwin.

Idowu, A. A. (2003). "An Appraisal of the Universal Basic Education Bill”, The Nigerian Social Scientist, 6(1), March, p. 27.

Nnodim, O. (2013). "Only Visionary Leaders Can Transform Nigeria - UNDP”, Punch Newspaper, Wednesday, August 28, p. 33.

Nwosu, K. I. (2011). "Food Security: A Panacea to National Development", Paper presented at the $75^{\text {th }}$ Annual NEC Meeting of the University of Nigeria Alumni Association, National Root Crops Research Institute, Umudike, Saturday, March 26, pp. 1-2.

Ogunlana, A. (2007). "Corruption: Dimensions and Implications for Development in Nigeria", Transparency: A Publication of the Central Bank of Nigeria, 1(2), 5.

Ogunsola, F. A. (1974). Legislation and Education in Northern Nigeria. Ibadan: Ibadan University Press.

Okunamiri, P. O. (2005). The Politics of Education: The Nigerian Experience. Okigwe: Fasmen Communications.

Ogar, M. (2013). "Ministers Underscore Effective Teaching System, Advocate Tutors' Professional Development”. The Guardian Newspaper, Thursday, January 10, p. 42.

Ogbuagu, C. S. A. (2006). "Igbo Business Practices in the Context of Globalization". Ahiajoku lecture, p. 70.

Onakemu, O. (2012). "Education Can Check Restiveness, Boko Haram". The Guardian Newspaper, Saturday, August 25, p. 53.

Onwuka, J. O. (2008). "Political Parties and Educational Development in the First Republic", in J. M. Kosemani and M. C. Anuna (eds.), Politics of Education: The Nigerian Perspective (2nd ed., p. 89). Enugu: El Demak Publishers.

Onyekanmi, R. L. (2012). "How Graft, Poor Staffing, Others Mar Public Varsities". The Guardian Newspaper, Wednesday, November 14, p. 2. 


\section{Macrothink}

Journal of Asian Development

ISSN 2377-9594 2017, Vol. 3, No. 2

Orgu, M. (2012). “Challenges of Nigeria's Education”. The Nation Newspaper, Thursday, November 15, p. 35.

Osoba, S. O. (1996). "Corruption in Nigeria: Historical Perspectives", Review of African Political Economy, 69, 371.

Osoba, S. O. and Fajana, A. (1984). "Education and Social Development during the Twentieth Century", in Obaro Ikime (ed.), Groundwork of Nigerian History (pp. 570-571). Ibadan: Heinemann Educational Books (Nig) Ltd.

Ota, E. N. (2012). "The Political Economy of Corruption in Nigeria, 1999-2012". UZU: Journal of History and International Studies, 3(1), 205.

Sall, E. (2006). "The Shape of Globalization", Paper presented at a 2-Day ASUU CODESRIA Initiative on Reforming Higher Education". National Scholar, 5(6), June.

Soniyi, T. (2013). "Lemu Report: National Assembly is Bleeding the Country". This Day Newspaper, Tuesday, October 8, p. 6.

Sule-Kano, A. (2005). "Education not a Commodity for sale". The National Scholar, A Publication of the Academic Staff Union of Universities (ASUU), 5(6), 4.

Taiwo, C. O. (1980). The Nigerian Education System: Past, Present and Future. Lagos: Nelson Pitman Limited.

Taiwo-Oguntuase, S. (2013). "Contending with Inadequate Faculty Staff in Nigerian Universities”, Daily Independent Newspaper, Wednesday, June 19, p. 37.

The Guardian Newspaper. (2010). "Editorial”, December 10, p. 19.

ThisDay Newspaper. (2013). “Editorial”, Tuesday, July 16, p. 15. 